\title{
Impact of Organizational Trust on Whistle-Blowing Intentions at Malaysian Enforcement Agency
}

\author{
Wan Najwa Arifah W. Ahmad, Fais Ahmad \\ ${ }^{I}$ School of Business Management, College of Business, Universiti Utara Malaysia, Sintok, Kedah Malaysia \\ ${ }^{2}$ School of Business Management, College of Business, Universiti Utara Malaysia, Sintok, Kedah Malaysia
}

\begin{abstract}
The current study investigated the relationship between organizational trust and whistle-blowing intentions at Malaysian Enforcement Agency. For further analysis, a sample of 346 employees working at Malaysian Enforcement Agency was selected using proportionate stratified random sampling method. For measurement, this study has adopted by Bews (1999) for organizational trust and adopted by Park (2009) for whistle-blowing intentions. To show the relationship between organizational trust and whistle-blowing intentions, this study using factor analysis and correlation analysis. The data analysis indicated that the organizational trust has positive impact on whistle-blowing intentions. The results also showed that organizational trust has significant and positive impact on the dimension of whistle-blowing intentions (internal whistle-blowing and external whistle-blowing).
\end{abstract}

Keywords: organizational trust, whistle-blowing intentions, internal whistle-blowing, external whistle-blowing, enforcement agency.

\section{INTRODUCTION}

In Malaysia, whistle-blowing action is not a popular way of reporting wrongdoing in organizations (Ghani, Galbreath, \& Evans, 2011), heavily influenced by ineffective whistle-blowing processes and systems (Pillay \& Dorasamy, 2011). Global Corruption Barometer (GCB) 2013 reports that 45 percent of people say they would not report the wrongdoing because it would not make any difference, showing lack of confidence in the existing laws and their enforcement. This is the most common reason given in 73 countries including some of the countries, where the majority of people would not be willing to report the wrongdoing. However, the main reason given in 32 countries, where the majority of people in the country would not report an incident of corruption because people are most afraid of reprisals.

Furthermore, Malaysia Corruption Barometer (MCB) 2014 found that the willingness of citizens to report corruption has decreased. Results from the interviews indicated that only 51 percent of respondents are willing to report an incident of corruption, which decreased from last year by 79 percent. Amongst those, 49 percent are not willing to report an incident. The key reason for not reporting is a fear of reprisals. The rest are not aware of where to report or feel that it would not make any difference. Therefore, it is clear from this responses that there is need to establish safe and effective mechanisms to facilitate and empower people to report incidences of corruption.

Since whistle-blowing situations often pose problems for whistleblowers, trust becomes an important facilitator for the decision to blow the whistle. Employees are more likely to blow the whistle when trust exists (Binikos, 2008). However, if organization retaliate against whistleblowers, then not only is the opportunity to address the wrongdoing lost, but trust in the relationship between the organization and the whistleblowers is also broken and employees morale is harmed. The suggestion is made that trust plays a role in employees' decisions to report the wrongdoing. If trust is harmed, it may result in the whistleblowers being discouraged to report irregularities by keeping quiet or perhaps pursuing external channels (Milliken, Morrison, \& Hewlin, 2003). Therefore, organizational trust viewed as a trigger to the occurrence of whistle-blowing intentions in the organization. 
Wan Najwa Arifah W. Ahmad \& Fais Ahmad "Impact of Organizational Trust on Whistle-Blowing Intentions at Malaysian Enforcement Agency"

\section{LITERATURE}

\section{Organizational Trust}

According to Shockley-Zalabak, Ellis, and Winograd (2000), organizational trust refers to the positive expectations of employees regarding the employer organization's behaviors based on the relationships, organizational roles, and interdependencies. Organizational trust is also known as institutional trust (Fox, 1974) or impersonal trust (Vanhala, Puumalainen, \& Blomqvist, 2011).

Trust has substantial impact on information sharing and exchange (Creed \& Miles, 1996; Dirks, 1999; Kimmel, Pruitt, Magenau, Konar-Goldband, \& Carnevale, 1980; Mellinger, 1959; O'reilly, 1978; Smith \& Barclay, 1997). Trust fosters communication and information sharing (Creed \& Miles, 1996). If employees trust the organization, they share their concerns without hesitation (Nikalaou, Vakola, \& Bourantas, 2011).

In addition, trust in organization will affect self-efficacy and confident of employees (Yang \& Mossholder, 2010). Employees with higher level of self-efficacy will share their concerns to make difference in their organization and employees who trust in their organization are feel more confident with the outcomes of their behavior and reactions of the organization. Therefore, organizational trust is very important to the organization because it will affects the behavior of employees to report organizational wrongdoing though speaking up is perceived to be a risky behavior that challenge the status quo (Detert \& Burris, 2007).

\section{Whistle-Blowing Intention}

Whistle-blowing has been defined as "the disclosure by organization members (former or current) of illegal, immoral, or illegitimate practices under the control of their employers to persons or organizations who may be able to effect action" (Near \& Miceli, 1985). This definition has been widely used in other studies (Brody, Coulter, \& Lin, 1999; Dekat \& Miceli, 1995; Elias, 2008; Hwang, Staley, Chen, \& Lan, 2008; James, 1995; Ponnu, Naidu, \& Zamri, 2008; Uys, 2000). Although it seems to be hurtful to organizational interests, but whistle-blowing may be managed to develop organizations (Gokce, 2013).

Whistle-blowing plays a positive function in enhancing accountability, transparency, and good governance in the organizations (Mohamed, Ahmad, \& Baig, 2015) because it is widely accredited as one of the most powerful method as a part of the internal control system in the organization to detect and prevent corruption, malpractices, and wrongdoings (Meng \& Fook, 2011; Transparency International, 2009).

Basically, there are two types of whistle-blowing namely internal and external reporting of wrongdoings (Dworkin \& Baucus, 1998; Park \& Blenkinsopp, 2009; Zhang, Chiu, \& Wei, 2009). If the wrongdoing is reported to parties within the organization, the whistle-blowing is internal, while if the wrongdoing is reported to parties outside of the organization, then the whistle-blowing is considered as external. According to Dworkin and Baucus (1998), the decision to blow the whistle either internally or externally depends on the reaction that will be taken by the organization.

Internal whistle-blowing occurs when the wrongdoing is reported to parties outside the chain of command, but within the organization. It include the board of directors, the audit committee, and a senior officer such as the chief executive officer or designated complaint recipient inside the organization (Finn, 1995). Reporting to co-workers (peer reporting) is not classified as whistleblowing (King, 1999). In contrast, external whistle-blowing occurs when the complaint recipient is outside of the organization. It include law enforcement agencies and regulators, professional bodies, external "watch dog" organizations and interest groups, and the media (Near \& Miceli, 1995).

King (1999) and Miceli and Near (1992) argue that internal and external whistle-blowing are conceptually similar. However, Barnett (1992) and Casal (1994) argue that they are different. Those who proposed that they are similar argue that the starting point of both is when an employees perceive wrongdoing in the organization (King, 1999). Both internal and external whistle-blowing requires employees to take an active part in reporting the wrongdoing instead of a more insidious act like sabotage, worse, or violence (Miceli \& Near, 1992).

\section{METHODOLOGY}

In this study, respondents were employees of enforcement agency in Malaysia. Quantitative approach was used in this study because allows the relationship between the variables identified and tested. In 
Wan Najwa Arifah W. Ahmad \& Fais Ahmad "Impact of Organizational Trust on Whistle-Blowing Intentions at Malaysian Enforcement Agency"

this study, that approach was also used to receive variety of responses from a number of subjects participated. Participants who were randomly selected from enforcement agency in Malaysia for this study were 346 employees from all departments. The instruction of the questionnaires describing this study was sent for each subject which is the direction for completing the questionnaires. A total of 346 subjects responded to the survey.

Of the 346 subjects, $272(78.6 \%)$ were males while 74 (21.4\%) were females. The status of sample was $62(17.9 \%)$ single, $275(79.5 \%)$ married, $8(2.3 \%)$ divorced, and $1(0.3 \%)$ others. For level of education background, 205 (59.2\%) were SPM, 41 (11.8\%) STPM, 18 (5.2\%) certificate, 44 (12.7\%) diploma, $27(7.8 \%)$ bachelor, $2(0.6 \%)$ master degree, and $9(2.6 \%)$ others.

\section{Organizational Trust Measurement}

Measurement of organizational trust was adapted from Bews (1999). Organizational trust were assessed using a 19-items measure that examined the employees' trust in the organization. Employees responded on a 1-5 Likert-type scale the extent to which they agreed with each statement as it reflected their present work environment. The cronbach alpha reliability for the aggregate measure of trust in the organization was $\alpha=0.758$.

\section{Whistle-Blowing Intention Measurement}

In measuring whistle-blowing intentions, this study has adopted instrument conducted by Park (2009). To measure the effects of whistle-blowing intentions is seen in two dimensions, namely internal and external whistle-blowing. The type of ordinal scale used is a 1-5 Likert-type scale. Internal whistleblowing measured with 3 -items. The reliability test result for this items is $\alpha=0.806$. External whistleblowing measured with 5-items. The cronbach alpha result is $\alpha=0.802$.

\section{ANALYSIS DATA}

In this study, the data collected were analyzed by using reliability test, factor analysis, and correlation analysis. Reliability test was used to see how far the scale is free from error and produces consistent results between multiple instruments of the variables (Gay \& Diehl, 1996). Factor analysis was used to determine the dimensions of the variables (Coakes \& Steed, 2010). Correlation analysis is a method used to assess the strength and direction of the relationship between two variables (Gay \& Diehl, 1996).

\section{FINDING}

\section{Data Screening}

In this process, reliability and normality of data are examined. Reliability values of organizational trust is $\alpha=0.819$ and whistle-blowing intentions is $\alpha=0.722$. In normality, skewness and kurtosis test values should be inside \pm 1.96 . Therefore, organizational trust and whistle-blowing intentions have a normal data.

\section{Factor Analysis}

KMO, bartlett's, MSA, and partial correlation were tested in the factor analysis. This test have satisfied the requirement to proceed the factor analysis. The KMO value should be above 0.50 , the bartlett's test was significant at $\mathrm{p}<0.05$, MSA values are well above 0.50 , and lastly partial correlation value should be below than 0.70 .

\section{Organizational Trust}

The factor analysis has shown that the KMO value is 0.864 . Bartlett's test value is significant at $\mathrm{p}<$ 0.05. In this study, six factors revealed in eigen value score and cumulative total is $61.426 \%$. However, after factor analysis it was found that there are four components only in rotated component matrix for organizational trust. The components (Factor 1, 3, and 4) should be discard from the analysis because not achieve a sufficient degree of reliability.

Table1. Reliability Test for Organizational Trust after Factor Analysis

\begin{tabular}{|l|l|}
\hline Organizational Trust & Cronbach Alpha after Factor Analysis \\
\hline Factor 2 (Trust) & 0.758 \\
\hline
\end{tabular}


Wan Najwa Arifah W. Ahmad \& Fais Ahmad "Impact of Organizational Trust on Whistle-Blowing Intentions at Malaysian Enforcement Agency"

Table 1 has shown that cronbach alpha value $(\alpha)$ for organizational trust after factor analysis. Factor 2 consists of 6 items which cronbach alpha value is 0.758 and renamed as trust. Therefore, this factor can be used for further analysis.

\section{Whistle-Blowing Intention}

The factor analysis has shown that the KMO value is 0.710 . Bartlett's test value is significant at $\mathrm{p}<$ 0.05 . In this study, two factors revealed in eigen value score and cumulative total is $63.462 \%$. After factor analysis, it was found that there are two components in rotated component matrix for whistleblowing intentions.

Table2. Reliability Test for Whistle-Blowing Intentions after Factor Analysis

\begin{tabular}{|l|l|}
\hline Whistle-Blowing Intentions & Cronbach Alpha after Factor Analysis \\
\hline Factor 1 (External Whistle-Blowing) & 0.802 \\
\hline Factor 2 (Internal Whistle-Blowing) & 0.806 \\
\hline
\end{tabular}

Table 2 revealed cronbach alpha value $(\alpha)$ for whistle-blowing intentions after factor analysis process. Factor 1 consists of 5 items which cronbach alpha value is 0.802 . Based on the meaning of each item, researcher has renamed as external whistle-blowing. Factor 2 consists of 3 items which cronbach alpha value is 0.806 . Refer to the meaning of each items, this factor renamed as internal whistleblowing. Therefore, all the factors can be proceeded for further analysis.

Relationship between Trust, Internal Whistle-Blowing, and External Whistle-Blowing

Table3. The Result of Correlation Analysis between Trust, Internal Whistle-Blowing, and External WhistleBlowing

\begin{tabular}{|l|l|l|}
\hline & Internal Whistle-Blowing & External Whistle-Blowing \\
\hline Trust & $0.233^{* *}$ & $0.146^{*}$ \\
\hline
\end{tabular}

Note: **Significant at confidence level $p<0.05$, *Significant at confidence level $p<0.01$

Table 3 has shown the relationship between organizational trust and whistle-blowing intentions dimensions. Correlation analysis results showed that trust has a significant relationship with internal whistle-blowing which value $r=0.233$ at $p<0.05$. While trust also has a significant relationship with external whistle-blowing which value $r=0.146$ at $p<0.01$. The results show that trust has a positive correlation with both internal and external whistle-blowing.

\section{DISCUSSION}

The researcher has been discussed the relationship between organizational trust and whistle-blowing intentions in enforcement agency at Malaysia. This study seeks to explore whether trust would encourage employees to disclose information about wrongdoing either internally or externally. This is because employees faced with organizational wrongdoing have a choices whether to report it internally or externally. This study indicated that trust have a significant and positive relationship to whistle-blowing intentions (internal whistle-blowing and external whistle-blowing).

Whistle-blowing intentions occurred when there was a trust in the relationship between supervisor and subordinates. Reporting to the supervisor will take place (internal whistle-blowing) when there is a strong relationship of trust between supervisor and subordinates. Employees are more likely to report internally when they place trust in the organization. The relationship between supervisor and subordinates will promote internal whistle-blowing if the supervisor's words can be trusted. This relates to an assurance that subordinates will not be victimised if they use these channels (internal whistle-blowing) to report unethical behavior. However, from the employees' action of reporting misconduct, whistleblowers not receiving gratitude for their efforts and the risks they have taken. But, many have been forced to resign or leave their jobs, denied promotion, no research support, and urged to drop charges.

In this study, employees who are working in the enforcement agency choose to report unethical behavior that happened in the organization internally. It may be considered to be a demonstration of loyalty and commitment to the organization (Somers \& Casal, 1994). This is because employees need to follow the reporting procedure in the agency, which is internal whistle-blowing will offers an earlier opportunity to correct the matter before the problem become worse. It also can prevent 
Wan Najwa Arifah W. Ahmad \& Fais Ahmad "Impact of Organizational Trust on Whistle-Blowing Intentions at Malaysian Enforcement Agency"

potential scandals that may embarrass and negatively impact the agency (Barnett, 1992). Thus, it can avoid the more damaging consequences if employees choose external whistle-blowing. This is because if employees report externally, the outsider will found the weaknesses of the agency. So that the agency's "dirty linen" is not aired in public (Near \& Miceli, 1985). But, if the problem is not resolved to the whistleblowers' satisfaction, the employees may decide to report the wrongdoing externally. This is because they perceived that the problem would not receive an appropriate response after they reported internally.

However, in this study, employees are more likely to blow the whistle externally when they see the same wrongdoing many times and consider their employers as an immoral person and their senior managers as an undemocratic and possibly complicit in the wrongful act (Harris, 2002). Employees will choose to make a report externally if the wrongdoing involved their own supervisor or top level of management and when employees fear retaliation from employer above the level of the supervisors. This is because employees felt more confident that their identity will not be disclosed if they report externally.

\section{CONCLUSION}

This study has successfully explored and examined the relationship between organizational trust and whistle-blowing intentions at enforcement agency in Malaysia. The reseacher found that trust has significant relationship with both internal and external whistle-blowing. Therefore, the existence of trust will give positive impact to whistle-blowing intentions in the organization.

\section{REFERENCES}

[1] Barnett, T. (1992). A preliminary investigation of the relationship between selected organizational characteristics and external whistle-blowing by employees. Journal of Business Ethics, 11, 949-959.

[2] Bews, N. F. (1999). A sociological analysis of the concepts 'post-industrial' and 'post-modern' and their effect on the notion of empoyer-employee trust. MA Dissertation: Rand Afrikaans University.

[3] Binikos, E. (2008). Sounds of silence: Organizational trust and decisions to blow the whistle. SA Journal of Industrial Psychology, 34(3), 48-59.

[4] Brody, R. G., Coulter, J. M., \& Lin, S. (1999). The effect of national culture on whistle-blowing perceptions. In Teach, J. Business Ethics, 3, 385-400.

[5] Creed, W. E. D. \& Miles, R. E. (1996). Trust in organizations: A conceptual framework linking organizational forms, managerial, philosophies, and the opportunity costs of controls. Sage Publications, Thousands Oaks, CA, 16-38.

[6] Detert, J. R. \& Burris, E. R. (2007). Leadership behavior and employee voice: Is the door really open? Academy of Management Journal,50(4), 869-884.

[7] Dirks, K. T. (1999). The effects of interpersonal trust on work group performance. J Appl. Psych, 84(3), 445-455.

[8] Dworkin, T. M. \& Baucus, M. S. (1998). Internal vs. external whistleblowers: A comparison of whistle-blowing process. Journal of Business Ethics, 17, 1281-1298.

[9] Finn, D. W. (1995). Ethical decision making in organizations: An employee organization whistle-blowing model. Research on Accounting Ethics, 1, 293-315.

[10] Fox, A. (1974). Beyond contract: Work, power, and trust relations. Faber and Faber, London.

[11] Gay, L. R. \& Diehl, P. L. (1996). Research Methods for Business and Management. Singapore: International Edition. Simon and Schruster (Asia) Pte. Ltd.

[12] Ghani, N. A., Galbreath, J., \& Evans, R. (2011). Predicting whistle-blowing intention among supervisors in Malaysia. Journal of Global Management, 3(1), 1-18.

[13] Hwang, D., Staley, B., Chen, T. Y., \& Lan, J. S. (2008). Confucian culture and whistle-blowing by professional accountants: An exploratory study. In Manage and Audit, J., 23(5), 504-526.

[14] James, G. (1995). In defense of whistle-blowing. In Hoffman, W. M. \& Mills Moore, J. Business Ethics: Readings and Cases in Corporate Morality. McGraw Hill, New York, 249-260. 
Wan Najwa Arifah W. Ahmad \& Fais Ahmad "Impact of Organizational Trust on Whistle-Blowing Intentions at Malaysian Enforcement Agency"

[15] Kimmel, M., Pruitt, D., Magenau, J., Konar-Goldband, E., \& Carnevale, P. (1980). Effects of trust, aspiration, and gender on negotiation tactics. J. Personality Soc. Psych, 38(1), 9-22.

[16] King III, G. (1999). The implications of an organization's structure on whistle-blowing. Journal of Business Ethics, 20(4), 315-326.

[17] Mellinger, G. (1959). Interpersonal trust and communication. J. Abnormal Soc. Psych, 52(3), 304-309.

[18] Miceli, M. P. \& Near, J. P. (1992). Blowing the whistle: The organizational and legal implications for companies and employees. Lexington: New York, NY.

[19] Miliken, F. J., Morrison, E. W., \& Hewlin, P. F. (2003). An exploratory study of employee silence. Journal of Management Studies, 40(6), 1453-1476.

[20] Near, J. P. \& Miceli, M. P. (1985). Organizational dissidence: The case of whistle-blowing. Journal of Business Ethics, 4(1), 1-16.

[21] Near, J. P. \& Miceli, M. P. (1995). Effective whistle-blowing. The Academy of Management Review, 20(3), 679-708.

[22] Nikalaou, I., Vakola, M., \& Bourantas, D. (2011). The role of silence on employees' attitudes 'the day after' a merger. Personnel Review, 40(6), 723-741.

[23] O'Reilly, C. (1978). The intentional distortion of information in organizational communication: A laboratory and field investigation. Human Relations, 31(2), 173-193.

[24] Park, C. W. (2009). Organizational silence and whistle-blowing on IT projects: An integrated model. Decision Sciences, 40(4), 901-919.

[25] Pillay, S. \& Dorasamy, N. (2011). Systemic factors moderating effective whistle-blowing: An exploratory study into a public service organization. African Journal of Business Management, 5(22), 9429-9439.

[26] Ponnu, C. H., Naidu, K., \& Zamri, W. (2008). Determinants of whistle-blowing. International Review of Business Research Papers, 4(1), 276-298.

[27] Shockley-Zalabak, P., Ellis, K., \& Winograd, G. (2000). Organizational trust: What it means, why it matters. Organizational Development Journal, 18(4), 35-48.

[28] Somers, M. J. \& Casal, J. C. (1994). Organizational commitment and whistleblowing: A test of the reformer and the organization man hypothesis. Group and Organization Management, 19(3), 270-284.

[29] Smith, J. \& Barclay, D. (1997). The effects of organizational differences and trust on the effectiveness of selling partner relationships. J. Marketing, 61(1), 3-21.

[30] Uys, T. (2000). Hero or traitor? The professional person as whistleblower. Paper presented at Indaba Hotel, 25-26 October 2000 at IRR Conference on Whistle-Blowing.

[31] Uys, T. (2000). The politicisation of whistleblowers: A case study. Business Ethics: A European Review, 9(4), 259-267.

[32] Uys, T. (2000). The politicisation of whistleblowers: A case study. Oxford: Blackwell Publishers.

[33] Vanhala, M., Puumalainen, K., \& Blomqvist, K. (2011). Impersonal trust: The development of the construct and the scale. Personnel Review, 40(4), 485- 513.

[34] Yang, J. \& Mossholder, L. W. (2010). Examining the effects of trust in leaders: A bases-and-foci approach. The Leadership Quarterly, 21(1), 50-63.

\section{AUTHOR'S BIOGRAPHY}

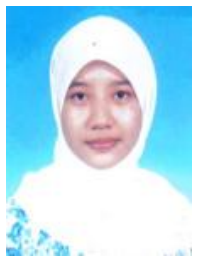

Wan Najwa Arifah W. Ahmad, I am a student of $\mathrm{PhD}$ in Management at Universiti Utara Malaysia, Kedah, Malaysia. Most studies focused on Organizational Behaviour which emphasizes on the relationship between workers and employer in organization. 